\title{
Diagnostics of the Legal Culture of Junior Schoolchildren
}

\author{
Ludmila Viktorovna Zemlyachenko ${ }^{1}$ \\ ${ }^{1}$ Federal State Budget Educational Institution of Higher Professional Education, "Mordovian State Pedagogical \\ Institute named after M. E. Evseviev", Russian Federation \\ Correspondence: Ludmila Viktorovna Zemlyachenko, Studencheskaya str., 11 a, Saransk city, 430007, Russian \\ Federation. E-mail: Milazemlyachenko@yandex.ru
}

\author{
Received: November 26, 2014 Accepted: December 18, 2014 Online Published: March 20, 2015 \\ doi:10.5539/ass.v11n8p72 URL: http://dx.doi.org/10.5539/ass.v11n8p72
}

\begin{abstract}
This article is devoted to the evaluation of efficiency of legal education of junior schoolchildren. The author suggests criteria for studying the level of legal culture: cognitive, emotional and evaluative, behavioral; describes methods and results of the research aimed at identifying the level of legal culture of primary school children in rural and urban areas. Quantitative and qualitative data processing helped to define special character of legal culture of primary school children in rural and urban schools in a comparative perspective.
\end{abstract}

Keywords: legal culture, legal education, junior schoolchild, criteria and levels of legal culture maturity

\section{Introduction}

According to official sources juveniles every year commit from 46000 (in 2013) to 80000 (in 2010) delinquency acts that Criminal Code regard as crime. They composed 6\% of the total number of crimes in 2013 (Central Office of the State Antidrug Committee, 2013). One of the reasons for this statistics is a low level of social and legal culture of schoolchildren, whose legal conscience is characterized by the absence of clear understanding of legal regulations, by difficulty to confront their behavior to requirements of law, by inability to apply legal knowledge in a given situation, by legal conscience dependence from negative influence of the community. All these reasons increase the significance of improvement of legal education system aimed at formation of legal culture of the younger generation, at preventative measures of illegal behavior of children, youth and in general, at reinforcement of legal order and legitimacy. Today this process enters the national level and presupposes the consolidation of efforts of different institutions aimed at the increase of legal culture level; with system of education playing the main part in this process. Statistics of juvenile delinquency in the Russian Federation shows that number of law violations increases at adolescence that is why it is necessary to legally educate and take preventive measures at primary school. Psychologists say that according to analyses cognitive, emotional and evaluative, behavioral spheres of personality responsible for the formation of orientations and models of lawful behavior are formed at this stage.

Means of shaping of legal culture of junior schoolchildren are thoroughly analyzed in experimental studies of E. A. Andreeva (2002), S. V. Brykina (2003), N. Y. Maydankina (2004), etc. Issues of early preventive measures of abnormal behavior are covered in works of O. A. Kuzchenko (2006), V. P. Filippova (2010) and others; preventive measures of juvenile delinquent behavior are discussed in studies of V. G. Stepanova (2006), I. A. Protasova (2008), S. T. Suleymanova (20006) and in others.

\section{Methodology}

\subsection{Criteria and Indicators of Legal Culture of a Personality}

Diagnostic basis of legal education is one of the conditions for its efficiency. Systematic studying of the nature of legal education of junior schoolchildren is an essential part of integral pedagogical process that provide information about fulfillment of educational goals and that is of great importance for programming and regulation of civil socialization, for advance of the process of legal education and for preventive measures of law violations at the following stages of studying.

Analysis of problems of legal education proves that modern teaching practice needs to improve the criteria and indicators of its efficiency. Basis for the development of criterial system are first of all the planned results of legal education at the starting point. Modern regulatory documents concerning the organization of education and 
upbringing of junior schoolchildren specify the following goals-results of legal education:

1) Establishment of humanitarian and democratic value orientations; forming respect for different opinion, development of skills of cooperation with adults and peers in different social situations, ability to avoid conflicts and to find ways out of a dispute (Federal State Educational Standard of Elementary General Education, 2009);

2) Forming the respect for rights, freedoms and responsibilities of a person, the tolerance and principals of culture of inter-ethnic communication, respect for the language, cultural, religious traditions, history and way of living of representatives of nations of Russia, introduction to the following values: legal state; civil society; law and order; politcultural world; personal and national freedom; trust to people, state institutes and civil society (Model of basic educational program of Elementary General Education, 2010);

3) Learning the value and content of such notions as devotion to Motherland, legal system and legal state, of such ethic categories as freedom and responsibility, of such worldview notions as honor, conscience, duty, etc.; development of competence and value idea of supremacy of law and need in law and order, social consensus and intercultural exchange (Program of development of educational element in educational institutions, 2013);

4) Shaping of juvenile law-abiding (Federal law "About principals of preventive measures for juvenile neglect and law violations", 1999).

To our opinion the given results of legal education could be fully revealed in the process of legal culture studying, because in its' structural aspect it is a unity of legal knowledge, believes and lawful behavior of a person that give opportunity to analyze and evaluate the maturity of personality for the further civil growth (Likhachev, 1996; Bogatikova, 2003; Levkovskay, 2011; Gulyaikhin, 2013; etc.). As noted by the researchers of the issues of civil and legal education (Igonin, 2011; Kupriyanov, 2014), components of legal culture have moral and ethical core and compose part of civil consciousness. We also used the results of researches devoted to the methodology of studying of legal culture of students (Nefedov \& Nefedova, 2006), (Muravieva, 2010).

In the process of experimental research we defined criterial system that helped us to study the nature of legal culture of junior schoolchildren (Zemlyachenko, 2009):

1) Cognitive (knowledge of social and legal norms, rules of conduct, including rules of safe living for oneself and others, basic rights, freedoms and responsibilities of schoolchild, son (daughter), citizen of multinational state; understanding the essence of human, civil, ethic and legal values, law and orderliness; awareness of one's rights and responsibilities);

2) Emotional and evaluative (appreciation of rights and freedoms of a person, of moral and legal norms; orientation to lawful behavior, respect for honor and dignity of other people, respect for the representatives of different nations; negative attitude towards violators of legal and social norms);

3) Behavioral (abilities and skills of socially good and lawful behavior; conscious performance of duties; formed personal qualities - politeness, discipline, tolerance, ability to implement one's rights and freedoms without violation of rights and freedoms of other citizens, ability to solve and prevent conflicts, to observe the laws of freedom, responsibility, cooperation and assistance).

Identification of criteria and indicators of legal culture is quite difficult task because legal sphere is closely connected to legal education, labor, moral, ecological and other directions of upbringing. Indicators of the defined criteria could be specified and complemented depending on the conditions of the region, on type and major courses of activity of educational institution, contingent of students, educational program.

According to the results of diagnostics based on the offered criteria students could be conditionally referred to the certain level of legal culture: high (presence of almost all given criterions), medium and low.

\subsection{Peculiarities of Studying of Cognitive, Emotional and Evaluative Components of Legal Culture}

Definition of actual level of legal culture is based on studying consciousness, feelings, behavior. Its external manifestations are always conditioned by the situation and imposed by the desire of a child to be accepted in a certain social group. Internal basis of legal culture - policies, value orientations that provide regular character of behavioral models, stability of civil and legal position of a personality are the most important but quite difficult to reveal and shape. In the course of work over the problem we have singled out pedagogical conditions fulfillment of which will ensure accurate results of diagnostics of legal culture of young schoolchildren.

While planning the research and preparing a set of diagnostic methods it is necessary to take into account that cognitive element of the phenomenon under investigation is already formed for the majority of students. Moreover it is not difficult to reveal; it would be enough to take an opinion poll, questionnaire survey, testing; it will give opportunity to classify students according to the level of their legal knowledge. 
System of psychological and pedagogical methods based on the influence on emotional part of personality help to study nature of emotional and evaluative criteria of legal culture:

1) Reading of belles-lettres on ethical and legal issues (fairy tales "Jack Frost", "Three sisters", "Cinderella", "Snow White and the Seven Dwarfs", "Tom Thumb", stories: "My word" (A. Panteleev), "Do not lie" (M. Zoschenko), "Offenders", "Who's the master?" (V. Oseeva), "Truth is the most valuable" (L. Tolstoy et al) and make legal analysis of heroes' deeds;

2) Watching videos, animated cartoon films ("Nu, pogodi!", "Tom\&Jerry", "Beauty and the Beast", "The Adventures of cat Leopold" and others) with the further discussion of peculiarities of legal relations between heroes;

3) Coloring of mood in setting of human rights violation ("Using crayons draw mood of a person who is treated politely/impolitely, rude");

4) Reflexive methods of evaluation and analysis of one's own negative behavior ("Describe how do you feel when you do not follow rules of conduct or offend somebody", "Do you do the right thing if you take something in supermarket without paying for it when nobody sees you");

5) Projective methods (Write a tale "My mood when I'm offended", "Show feelings of an offended person by mimicry and pantomimicry", "Paint mood of a child whose favorite toy was taken away"). At this stage teacher's task is to stir up positive feelings of children towards people, to feel inner turmoil and offences of others, to consider one's own behavior from the point of view of influence on surrounding people, analyze one's emotions in setting of rights and freedoms violation and to realize that everybody have similar emotions.

While studying emotional and evaluative criteria it is necessary to discuss questions topical for children, for example: "How do you treat your classmates?", "How do you treat people of other nations?", "How do you treat children who do not follow rules of behavior and offend others?" Maturity level of emotional and evaluative criteria indicator is defined by qualitative processing of students' answers.

\subsection{Peculiarities of Studying of Behavioral Component of Legal Culture}

Studying of behavioral component of legal culture is the most complex one. In the majority of researches it is diagnosed by methods of questionnaires, discussions, that is why the results are footless, illusory and mainly show the level of knowledge and marks of students. The most informative diagnostic methods are: observation (activated, open and secret), that could be implemented by shooting the whole academic day; analysis of products of children's activity (paperwork, creative tasks, etc.); experimental methods (installation of educating setting, settings for modelling the behavior, organization of socially important events "Charity acts", "Let's help nature", etc.); carrying out technics for self-analysis of motives for participation of schoolchildren in any activity, defining the level of junior schoolchildren social activity. For example you can offer children different situations to analyze and choose the behavior model: "What do you usually do if somebody violates rules of conduct in school?", "What will you do if somebody breaks rules of a game?", "What do you usually do if you are not allowed to express your opinion?", etc. It is very important not only to define the maturity level of certain indicators of legal culture, but also to show children negative perspectives of such behavior. Use different methods and technics that help to reveal civil and legal attitude of children and to influence it at the same time:

1) Method of evaluation of negative consequences of unlawful behavior that give a child opportunity to feel the consequences of his/her actions: "If a child violates rules of conduct in school, at home, on the street then he/she will be treated distrustfully, suspiciously, other children wouldn't like to communicate, to play with him/her. He/she will be spoken about badly, he/she will be considered to be ill-mannered. Do you want to be treated like this?";

2) Method of revealing the intentions, that help to understand the motivation of child's actions and of his/her behavior in a whole: "Let's find out why junior schoolchild takes other's things, tries smoking, fights, curses. What does he/she get from it?";

3) Demonstration of personal and collective significance of socially positive tasks: "Let's define what advantage will we get if we don't argue? What beneficial results will we reach if we help each other? etc.";

4) Method of creation of social prospect: "Let's imagine how our lives will change if we don't offend each other, fight, take other's things, curse, etc."; "How will change the attitude towards a child who will stop to commit bad actions? How long will it take to change the attitude towards him/her?".

Objectivity and credibility of the results are ensured by the participation of all subjects of educational process: parents, teachers, psychologist, and social teacher. 
While choosing diagnostic tools for processing and interpretation of results of studying legal culture of rural and urban schoolchildren it is necessary to take into consideration special influence of a particular community on a personality. Thus in rural area it is easier to study all components of the phenomena under investigation due to a locality of the environment, little number of population, more frank relations, more close communication between a teacher and children.

\section{Results}

While studying the problem we conducted diagnostics of legal culture of junior schoolchildren of rural and urban schools of the Republic of Mordovia. The research is based on the assumption that the level of legal culture of urban junior schoolchildren is higher than in rural area. The major task of the research was to make a comparative analysis of the level and nature of cognitive, emotional and evaluative and behavioral components of legal culture of junior schoolchildren in rural and urban areas.

\subsection{Results of Studying of Cognitive Component of Legal Culture}

First unit of questions and tasks was aimed at the studying of cognitive component. Analysis of the results showed that both urban and rural junior schoolchildren know enough about national symbols, state structure, rights and duties of a Russian citizen. Despite some difficulties to expand upon the essence of rights and duties, students named quite a long list of personal, social, cultural rights (to a decent life, labor, rest, etc.), stated in the Constitution of the Russian Federation, UN Convention of the rights of a child. As for the duties, junior schoolchildren mainly realize the significance of implementation of duties of a student ( $85 \%$ of respondents), of a son (daughter) (15\%), of preserving health (20\%).

Majority of students know rules of behavior in school, public places and rules of communication. Significant part of respondents from urban and rural schools is aware about the consequences of constant violations of legal norms: punishment $-25 \%$, low level of education - 35\%, expulsion from school - $35 \%$, isolation from normal communication and friendship - 10\%, criminal penalty and fine for parents $-10 \%$.

Results of questionnaire and comparison of age selection showed that level of legal knowledge increases to $4^{\text {th }}$ grade and that is obviously connected to organization of legal education and enrichment of live experience of children. Comparison of research results proved that urban schoolchildren have higher cognitive criteria of legal culture than rural, due to the fact that they have bigger social connections, more informational resources, goal-oriented systematic legal awareness, and more frequently apply legal knowledge in different life situations. According to the received data we singled out four groups of students corresponding to 4 levels of maturity of legal knowledge: high, medium, alarming and low. Results are shown in Figures 1-2.

Urban area

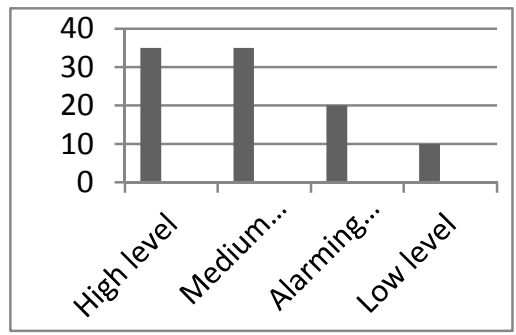

Rural area

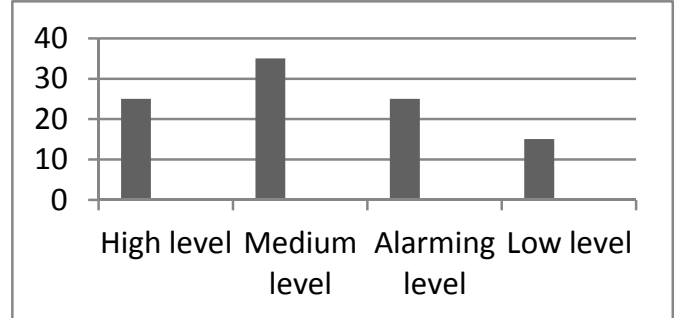

Figures 1-2. Distribution of junior schoolchildren according to their level of legal knowledge

\subsection{Results of Studying of Emotional and Evaluative Component of Legal Culture}

We used a set of methods (questionnaire, observation, discussion, testing) while studying emotional and evaluative criterion. In order to evaluate emotional component of the criterion we offered children to watch a video fragment about violation of human rights and to express their emotions by different colors: dark - if they have negative emotions, light - if they have positive feelings. We also used modified technic "Staircase". In this technic on stairs of a staircase (the highest stairs - positive estimation of the behavior, the lowest - negative estimation of the behavior) it is necessary to put: a child violating rules of behavior, rights of other children; oneself in the similar situation. According to the results about $90 \%$ of all interviewed rural and urban schoolchildren have negative attitude toward people violating rules of behavior. But if a child himself/herself violated the rules then $50 \%$ of students explain it by turn of events, subjectively evaluating their actions without 
defining their guilt. $25 \%$ of respondents take reflexive and analytical position: they promise to themselves that "they can't behave like this", "they won't behave like this anymore". $25 \%$ of students do not think about such situations.

There are different motives of lawful behavior: external ("for order in life") as well as internal ("...to be able to say that you are a person of culture"). Students also speak about following motives: normative ("...for constant order" (25\%), "people must obey rules of conduct and laws $(25 \%)$; need for recognition and respect ("to be loved and respected" (25\%); desire to avoid punishment ("so that parents and a teacher won't scold", "so that adults won't make comments" (35\%); desire to correspond to parent's requirements ("not to upset parents", "everyone in our family is educated and well-mannered") (5\%); aspiration to optimize process of education ("to have silence during classes and order during brakes", "to have silence during classes so that everyone is comfortable to study") (15\%).

As for attitude towards representatives of other nations there is a tendency for manifestation of national intolerance: $20 \%$ of students have medium, selective and only externally decent attitude towards people of other nations; $5 \%$ have negative attitude. $35 \%$ of junior schoolchildren get annoyed when people speak another language; moreover there are answers with hostile attitude towards other nations $(10 \%)$. This tendency is typical for students of urban schools.

Comparison of research results showed that rural schoolchildren have higher emotional and evaluative criteria of legal culture then urban ones. Results are shown in Figures 3-4.

Urban area

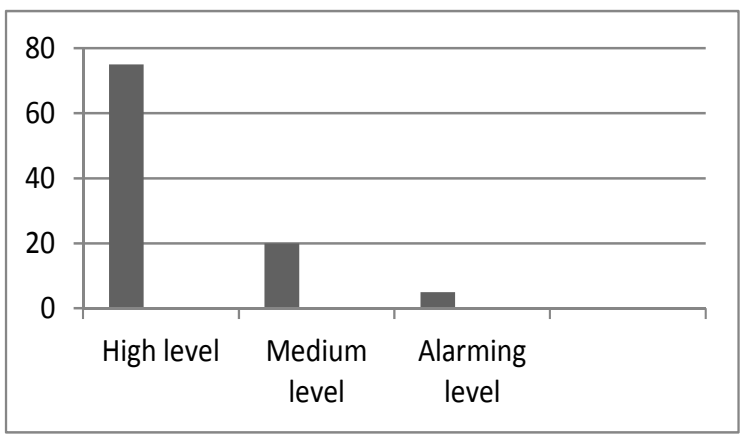

Rural area

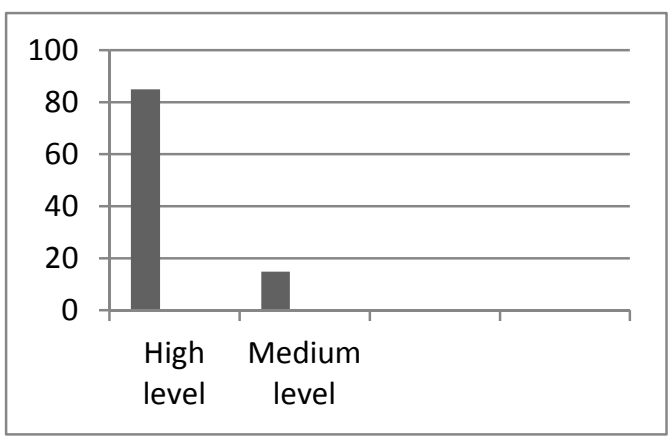

Figures 3-4. Distribution of students according to the level of emotional and evaluative criterion of legal culture

\subsection{Results of Studying of Behavioral Component of Legal Culture}

While studying behavioral criteria of legal culture we used methods of active observation, discussion, experimental methods of setting educational situations. Children were offered to design a behavior if situation requires to fulfill duties of a student (to do homework), work assignments of a teacher, to protect rights of other children and their own rights. According to the results the majority of schoolchildren take up a responsible position while fulfilling educational and work duties and that is mainly conditioned by authority of a teacher, of an adult.

Situations of designing a behavior in case if child's rights were violated were singled out in a special group. In situation "If you see that a boy hit a girl" $95 \%$ of students prefer to take active position and to help a girl. Children show the same activity in a situation if a classmate is aggressive towards them $(65 \%)$, and $60 \%$ of students will show the same response.

The majority of students ( $80 \%$ of interviewed) are not aggressive towards their classmates and friends, $5 \%$ gave answers "seldom", "sometimes", $15 \%$ answered positively. In situations when "they don't have opportunity to express themselves", only $5 \%$ of respondents would take actives Table position "will ask to give the floor" and $30 \%$ of children will display aggressiveness. All these facts show the absence of ability to respect human rights and freedoms in situations of modeling and setting of communication. As for the attitude towards adults in the majority of cases schoolchildren are polite, however undeliberate violation of private space of a child by an adult causes aggression. $35 \%$ of students admitted that they are not always polite to their parents.

Therefore demonstration of legal culture in the process of modeling behavior and activity of junior schoolchildren of urban and rural schools has the following features: proper stability of attitude toward 
educational and working activity; energy, assistance in case of violation of rights of other people; aggressiveness and hostility or inaction and indifference while protecting one's own rights; absence of sTable model of building relations with peers and adults.

Students answered a set of questions regarding their attitude towards alcohol and drugs as one of the reasons for committing violations. The majority (90\% of rural and urban schoolchildren) is aware that drugs are harmful for health and life. Besides $25 \%$ of respondents already tasted alcohol.

According to observations, talks with teachers, questionnaires we received data about unlawful actions of students (Table 1).

Table 1. Unlawful actions of pupils of primary school

\begin{tabular}{lll}
\hline Unlawful actions & Urban area \% & Rural area \% \\
\hline Assaults & 12 & 6 \\
Fights & 36 & 26 \\
Petty thefts, disorderly conduct & 12 & 4 \\
Rudeness to parents & 35 & 18 \\
Violation of discipline in class & 12 & 6 \\
Rudeness to strangers & 12 & 0 \\
Violation of school discipline & 35 & 8 \\
Neglect of homework & 20 & 10 \\
Deception & 28 & 16 \\
Smoking & 25 & 23 \\
Drinking alcohol & 25 & 25 \\
Vulgar language & 20 & 20 \\
Violation of traffic rules & 33 & 26 \\
\hline
\end{tabular}

According to Table 1 we can make a conclusion that number of unlawful actions of urban schoolchildren is a little higher than the same indicators of rural schoolchildren. Results of studying of behavioral component of legal culture are shown in Figures 5-6.

Urban area

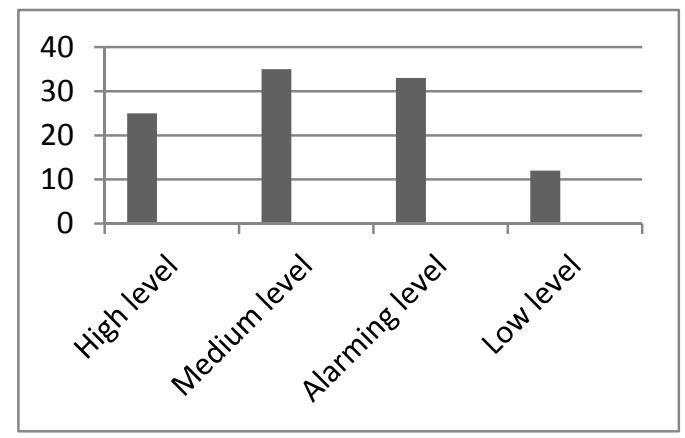

Rural area

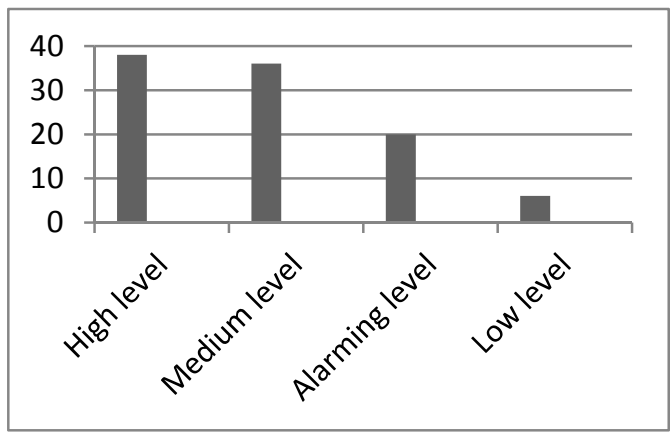

Figures 5-6. Maturity level of behavioral component of legal culture of junior schoolchildren

Comparative analysis of the results of rural and urban schools students prove that their indicators differ in high, alarming and low levels: children from rural areas have lawful behavior in 38\% cases comparing to $25 \%$ for urban schoolchildren. There are more children with alarming behavioral level in cities (25\%) in comparison with rural students $(20 \%)$.

\section{Discussion}

Processing of received results helped to define the character of legal culture of primary schoolchildren in rural and urban areas according to maturity levels of its criteria. Insufficiency of legal knowledge in rural area is 
balanced by high level of emotional and evaluative and behavioral criteria caused by the influence of specific features of rural community on personality. Urban conditions form sufficient awareness of statue of law, rights and responsibilities of children. However behavioral component of legal culture is on the medium level approaching the low level.

Negative actions of junior schoolchildren are not dangerous for the society in most cases, whereas the number of unlawful actions of junior school age increases to the end of $4^{\text {th }}$ grade and to the beginning of early teenage years. According to the research Table behavioral deviations are not typical for junior schoolchildren. However some of them must be considered as a precondition for the following acquisition of antisocial experience that could lead to difficulty of up-bringing and further violations of law provided unfavorable educational conditions. Number of children, who has quite serious violations of law and order, increases at the higher level of education (15\% of total number of students of 5-6 grades). This underlines the necessity of thoughtful approach to legal education, advance of forms and methods of legal awareness of junior schoolchildren, their orientation on practical application of knowledge, to shaping well-balanced motives and habits of lawful behavior.

\section{Conclusion}

Thus one of the key conditions for the legal education efficiency is a regular tracking of level of legal culture of junior schoolchildren because it ensures a feedback, gives opportunity to change and make tasks more specific to every subject of diagnostics, differentiate them for teachers, parents and students themselves; it also contributes to fulfilment of stated goals of shaping legal culture taking into account requirements of the society and personal interests. Promising direction for further investigation on the subject is a development of criterial framework and process chart of monitoring of efficiency of legal education and of up-bringing of junior schoolchildren; this will provide qualitative organization of the formation process of legal culture of children and youth.

\section{Acknowledgements}

This study was conducted with the assistance of Ministry of Education and Science of the Russian Federation, as a part of the project 2.1.1 Solving of systemic problems concerning the development and introduction of humanitarian technologies in educational practice at the premises of scientific and educational centers and research laboratories of Strategic Development Program of MordSEI for 2012-2016.

\section{References}

Andreeva, E. (2002). Ethic and legal upbringing of young schoolchildren. PhD Dissertation, Kazan.

Bogatikova, O. (2003). Shaping legal culture of junior teenagers in general education school. Synopsis of a thesis, Penza.

Brykina, S. (2003). Formation of legal images of young schoolchildren in extracurricular activity. Synopsis of a thesis, Penza.

Federal law "About principals of preventive measures for juvenile neglect and law violations" No. 120-FL. (1999, June 24). Retrieved December 9, 2014, from http://base.garant.ru/12116087/

Federal State Educational Standard of Elementary General Education. (n. d.). Retrieved December 9, 2014, from http://xn--80abucjiibhv9a.xn--p1ai/\%D0\%B4\%D0\%BE\%D0\%BA\%D1\%83\%D0\%BC\%D0\%B5\% D0\%BD $\%$ D1 \%82\%D1\%8B/922/\%D1\%84\%D0\%B0\%D0\%B9\%D0\%BB/748/\%D0\%A4\%D0\%93\%D0\%9 E\%D0\%A1_\%D0\%9D\%D0\%9E\%D0\%9E.pdf

Filippova, V. (2010). Pedagogical conditions for preventive measures and coping with abnormal behavior of junior schoolchildren. PhD Dissertation, Cheboksary.

Gulyaikhin, V. (n. d.). Legal culture as a subject of scientific research: Methodological approaches, structure and criterions of evaluation. Retrieved December 9, 2014, from http://e-notabene.ru/lr/article_635.html

Igonin, A. (2011). Theoretic model of formation of civil position of child's personality in socio-cultural sphere of educational institution. Humanitarian sciences and education, 4, 113-118.

Kupriyanov, A. (2014). Legal education as a part of civilized nature of the society provided persistently developing community. Humanitarian sciences and education, 1, 141-144.

Kuzchenko, O. (2006). Pedagogical conditions for preventive measures of children's abnormal behavior at transition stage from preschool to junior school age. PhD Dissertation, Volgograd.

Levkovskaya, N. (2011). Shaping legal culture of junior schoolchild. Synopsis of a thesis, Volgograd.

Likhachev, B. (1993). Pedagogy: Manual for universities. Moscow: Prometey. 
Maidankina, N. (2004). Pedagogical conditions for shaping principles of legal culture at the preliminary stages of socialization of personality (senior preschool and junior school age). $\mathrm{PhD}$ Dissertation, Ulyanovsk.

Model of basic educational program of Elementary General Education. (n. d.). Retrieved December 9, 2014, from http://obrazovanie.vladinfo.ru/edu/files/3801_10.07.20-\%D0\%9F\%D1\%80\%D0\%B8\%D0\%BC\% D0\%B5\%D1\%80\%D0\%BD\%D0\%B0\%D1\%8F \%D0\%BF\%D1\%80\%D0\%BE\%D0\%B3\%D1\%80\%D0\% B0\%D0\%BC\%D0\%BC\%D0\%B0_\%D0\%9D\%D0\%9E\%D0\%9E.pdf

Muravieva, K. (2010, February 15). Criterions, indicators and levels of maturity of legal culture of a student of law school by means of the English language. Materials of International extramural scientific conference "Urgent problems of modern pedagogy", 2(I). Novosibirsk: Pub. "ENSKE”. Retrieved December 9, 2014, from http://sibac.info/11661

Nefedov, S., \& Nefedov, M. (2006). Criterions of maturity of students legal culture. Polzunovskiy herald, 3, 241-244.

Program of development of educational element in educational institutions. (n. d.). Retrieved December 9, 2014, from http://turcentrrf.ru/d/358156/d/vk.pdf

Protasova, I. (2008). Activity of social teacher regarding preventive measures of delinquent behavior of teenagers in general education institution. Social pedagogy, 3, 70-79. Retrieved December 9, 2014, from http://www.dfo.fskn.gov.ru/analitika/2779-20122013.html

Stepanov, V. (2006). Psychology of troubled schoolchild: Manual. Moscow: Academy.

Suleymanova, S. (2006). Delinquent behavior of teenagers in modern Russian society: Factors and social control. PhD Dissertation, Penza.

Zemlyachenko, L. (2009). Civil and legal education of junior schoolchildren in traditional culture of the region. Periodicals of higher educational institutions. Povoljsk region. Humanitarian sciences, 2, 85-93.

\section{Copyrights}

Copyright for this article is retained by the author(s), with first publication rights granted to the journal.

This is an open-access article distributed under the terms and conditions of the Creative Commons Attribution license (http://creativecommons.org/licenses/by/3.0/). 